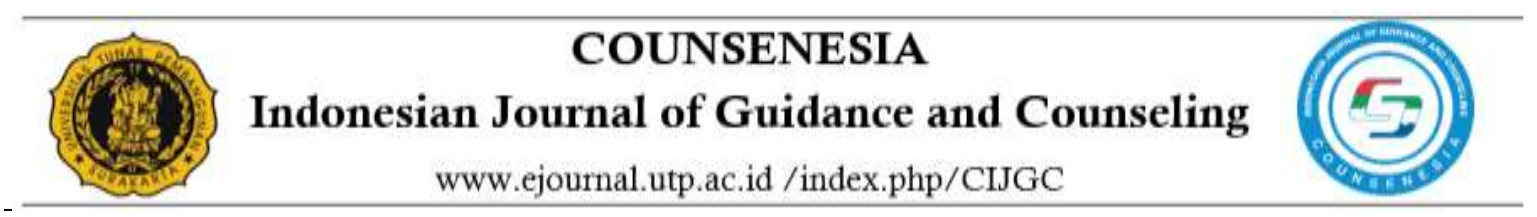

\title{
HUBUNGAN FATHERLESS DENGAN PENYESUAIAN SOSIAL REMAJA IMPLEMENTASI PELAKSANAAN LAYANAN BIMBINGAN KONSELING DI SEKOLAH
}

Dwi Dasalinda ${ }^{1}$, Yeni Karneli ${ }^{2}$

${ }^{1}$ Universitas Muhammadiyah Prof. Dr Hamka, ${ }^{2}$ Universitas Negeri Padang Email:dwidasalinda@gmail.com.

\section{Info Artikel Abstrak}

Riwayat Artikel Diterima: 23 Mei 2021 Disetujui: 20 Juni 2021 Publikasi: 28 Desember 2020
Kemampuan penyesuaian sosial yang baik pada remaja merupakan sebagai keberhasilan untuk menyesuaikan diri terhadap orang lain pada umumnya dan terhadap kelompok pada khususnya, sehingga menjadikan remaja dapat berkembang secara optimal. Namun tidak semua remaja mampu melakukan penyusuai diri dengan biak. Hal ini dikarenak tidak hadirnya figur yang menjadi teladan dalam penyesuai sosial yaitu fatherless. Penelitian ini bertujuan untuk mengetahui hubungan fatherless terhadap penyesuaian sosial remaja pada siswa SMA Negeri 10 Jakarta Pusat. Metode penelitian yang digunakan adalah penelitian kuantitatif asosiatif deskriptif sampel dalam penelitian ini berjumlah 123 siswa, yang dipilih menggunakan teknik probability sampling. Instrumen penelitian ini menggunakan skala fatherless dengan tingkat reabilitas 0,913 pada kategori sangat tinggi dan skala penyesuaian diri dengan tingkat reabilitas 0,875 pada kategori sangat tinggi. Penelitian ini dianalis dengan menggunakan uji koefisien regresi sederhana dengan bantuan SPSS 20.00. Hasil penelitian secara umum menunjukkan rata-rata fatherless sebesar $80 \%$ pada kategori tinggi dan penyesuaian sosial remaja $75 \%$ pada kategori tinggi. Bedasarkan uji koefisien regresi sederhana dengan membandingkan nilai Sig dengan 0,05 diperoleh $(0,000<0,05)$ yang berarti terdapat hubungan yang signifikan antara fatherless dengan penyesusian sosial. Berdasarkan hasil penelitian dapat diimplementasikan dalam pelaksanaan layanan dalam menganalisis perilaku siswa dalam penyesuaian sosialnya.

Kata kunci : fatherless, penyesuaian sosial, remaja

The ability of good social adjustment in adolescents is a success to adapt to other people in general and to groups in particular, so that adolescents can develop optimally. However, not all adolescents are capable of reproducing themselves. This is due to the absence of role models in the social conformer, namely fatherless. This study aims to determine the relationship between fatherless and adolescent social adjustment in SMA Negeri 10 Jakarta Pusat. The research method used is descriptive associative quantitative research. The sample in this study amounted to 123 students, who were selected using simple random sampling technique. The research instrument used a fatherless scale with a reliability level of 0.913 in the very high category and a self-adjustment scale with a reliability level of 0.875 in the very high category. This study was analyzed using a simple regression coefficient test with the help of SPSS 20.00 . The results of the study generally show that the average fatherless is $80 \%$ in the high category and the social adjustment of adolescents is $75 \%$ in the high category. Based on the simple regression coefficient test by comparing the Sig value with 0.05 , it is obtained $(0.000<0.05)$, which means that there is a significant relationship between fatherless and social adjustment. Based on the research results, it can be implemented in the implementation of services in analyzing student behavior in their social adjustment.

Keywords: fatherless, social adjustment, adolescents

(C) 2021 Universitas Tunas Pembangun Surakarta

ISSN: 2746-3532 (Online) ISSN: 2807-2235 (Print) 


\section{PENDAHULUAN}

Siswa pada tingkat pendidikan Sekolah Menengah Atas (SMA) merupakan individu pada fase perkembangan remaja. Fase remaja dikenal sebagai masa transisi menuju dewasa.. Salah satu tugas perkembangan masa remaja yang tersulit adalah berhubungan dengan sosial (Hurlock, 1994). Untuk memenuhi tugas perkembangan sosial tersebut, menuntut remaja untuk memiliki kemampuan dalam menilai situasi sosial dan menentuan perilaku yang baik atau tepat pada kondisi sosial tertentu. Kemampuan remaja dalam menangani kondisi sosial disebut dengan penyesuaian sosial (Sheikhi, 2001; Setianingsih, Uyun, \& Yuwono, 2006; Endah, 2013). Penyesuaian sosial merupakan kemampuan individu untuk bereaksi secara efektif dan sehat terhadap realitas sosial, situasi dan hubungan sosial sehingga individu dapat melakukan pemenuhan kebutuhan dengan perilaku yang memuaskan dan cara yang dapat diterima (Nurhusni, P. A., 2017).Penyesuaian sosial menjadi sangat penting dalam fase remaja, karena untuk meminimalisir timbunya konflik internal menyangkut peran dan krisis identitas pada remaja, yang memunculkan pertanyaan tentang siapa dirinya, bagaimana mengambil peran yang tepat dalam berbagai kondisi, dan interaksi di lingkungannya dalam penyesuaian sosial (Kristianawati, E., \& Djalali, M. A. A. , 2014). ).hal ini dikarenakan tugas perkembanan remaja tidak hanya di dalam rumah, namun juga diluar rumah berkaitan dengan lingkungan sosialnya, maka dari itu remaja harus mampu melewati tugas perkembangannya dan mengembangkan kemampuan penyseuai sosial (Putra, K. M. D., 2018).

Penyesuaian sosial yang baik menjadi sebuah keberhasilan bagi remaja untuk menyesuaikan diri terhadap orang lain pada umumnya dan terhadap kelompok pada khususnya (Hurlock, 2000). Penysesuaian sosial remaja terdiri dari upaya menyesuaikan diri dengan lingkungan keluarga, sekolah, dan masyarakat (Maharani, O. P., \& Andayani, B., 2003). Remaja yang berhasil melakukan penyesuaian sosial dengan baik mampu mengembangkan sikap sosial yang menyenangkan, seperti kesediaan untuk membantu orang lain, meskipun mereka sendiri mengalami kesulitan (Lestari, D. S., 2016). Remaja yang memiliki kemampuan penyesuaian sosial yang tinggi akan memahami kondisi lingkungan dengan baik dan menampilkan respon-respon yang sesuai dengan keadaan dirinya dan lingkungan sosialnya, serta berperilaku sesuai dengan norma yang berlaku dalam lingkungan sosial (Andriyani, J., 2016). Remaja dengan kemampuan penyesuaian sosial dengan baik, tentunya akan mampu melewati masa remajanya dengan lancar dan diharapkan ada perkembangan ke arah kedewasaan yang optimal serta dapat diterima oleh lingkungannya (Prihartanti, 1989). Selanjutnya penyesuaian sosial ynag baik bagi remaja adalah mampu bertanggung jawab secara sosial, mengembangkan kemampuan intelektual dan konsep-konsep yang penting bagi kompetensinya sebagai warganegara dan berusaha mandiri secara emosional (Havighurst dalam Hurlock, 1980). Oleh karena penyesuaian sosial menjadi kemampuan yang harus dimiliki oleh remaja. Namun tidak semua remaja mampum melakukan penyesuaian sosial dengan baik (Wardani \& Apollo, 2010).

Menurut Kartono (2005), bentuk ketidakmampuaan penyesuaian sosial adalah pengabain sosial, sehingga mendorang remaja untuk berperilaku juvenile delinquency (kenakalan remaja). Selanjutnya Kemampuan penyesuaian sosial yang rendah pada remaja akan kesulitan dalam memahami situasi dan menampilkan respon yang tidak sesuai dengan lingkungan sosialnya (Susilowati, E., 2013). Sehingga menimbulkan permasalahan yang semakin kompleks, seperti siswa yang tidak disukai oleh teman sekelasnya atau terisolir (Wardani, R.,2010), remaja yang tidak bahagia (Kumalasari, F., \& Ahyani, L. N., 2012). Selanjutnya perilaku yang ditunjukkan remaja cenderung rendah diri, tertutup, suka menyendiri, kurang adanya percaya diri serta merasa malu jika berada diantara oranglain atau situasi yang terasa asing baginya. Kumalasari, F., \& Ahyani, L. N. (2012).. Pada kondisi ini, remaja menjadi rentan untuk terlibat pada kasus-kasus kriminalitas akibat pengaruh kekuatan yang tidak baik dalam lingkungan sosialnya, seperti resiko pemakaian obat terlarang, 
kekerasan atau kegiatan seksual yang tidak aman (Gottman \& DeClaire dalam Sari, 2005). Pada diri remaja, pengaruh lingkungan dalam menentukan perilaku diakui cukup kuat. Walaupun remaja telah mencapai tahap perkembangan kognitif yang memadai untuk menentukan tindakannya sendiri, namun penentuan diri remaja dalam berperilaku banyak dipengaruhi oleh tekanan dari kelompok teman sebaya (Papalia, D E., Olds, S. W., \& Feldman, Ruth D., 2001). Permasalahan-permasalahan tersebut menuntut suatu penyelesaian agar tidak menjadi beban yang dapat mengganggu perkembangan selanjutnya.

Usaha siswa dalam penyesuaian dengan lingkungan, siswa terkadang dihadapkan pada kondisi sulit, misalnya: pertama, pola perilaku yang dikembangkan di rumah, hal ini menimbulkan kesulitan hubungan sosial di luar rumah; kedua, rumah yang kurang memberikan teladan yang baik pada perilak anak; ketiga, kurangnya motivasi untuk belajar menyesuaikan diri. Hal ini banyak terjadi karena pengalaman sosial awal yang tidak menyenangkan; keempat, anak tidak mendapatkan bimbingan dan bantuan yang cukup dalam proses belajarnya (Suharti, N., 2016). Oleh karena itu peran orang tua dalam keluaga mempengaruhi dalam pengembangan penyesuaim sosial pada remaja (Lestari, S, 2012). Kemampuan remaja dalam melakukan penyesuaian sosial memperoleh bekal kemampuan yang telah di pelajari dari sejak lahir hingga remaja ialah lingkungan keluarga dan proses dari pengalaman baru yang dialami dalam berinteraksi di lingkungan sosialnya. Menurut Schneider (Ali, 2004) mengatakan bahwa lingkungan keluarga merupakan salah satu faktor terpenting dalam menentukan penyesuaian sosial remaja.. Inayati (1995) menjelaskan bahwa dalam konteks keluarga, ibu dan ayah mempunyai peran yang berbeda namun saling mendukung. Peran ibu selama ini didefinisikan begitu lengkap dan detail, sedangkan peran ayah kurang diperhatikan.

Hal ini ada kecenderungan anggapan bahwa ayah hanyalah pencari nafkah dalam keluarga. Afiatin (2001) dominan remaja yang rendah penyesuaian sosial cenderung berperilaku nakal, dikarenakan memiliki masalah dalam berhubungan dengan anggota keluarga dan adanya konflik dengan ayah. Strom (2002) menjelaskan peran ayah dalam kehidupan remaja menunjukkan bahwa ayah yang terlibat dalam kehidupan remaja, terutama dalam pendidikan dan pergaulannya akan meningkatkan kemampuan remaja dalam pendidikan dan social skill. Hetherington dkk. (Lamb,1992) menjelaskan bahwa kehadiran ayah baik secara fisik dan psikia akan membantu anak dalam pemantapan hubungan dengan orang lain, penyesuaian perilaku, dan sukses dalam menjalin hubungan dengan lawan jenis. Senada dengan hal tersebut, Lamb (1992) menjelaskan bahwa seorang ayah yang tidak berada dalam kehidupan anak akan mempengaruhi peran jenis, moralitas, prestasi, dan psikososial anak.Sehingga dapat disimpulakn salah satu faktor yang mempengaruhi kemampuan penyesuaian sosial siswa adalah fatherless (Rahayu, S. 2019).

Fatherless adalah ketiadaan peran dan figur seorang ayah dalam kehidupan anak. Ketiadaan peran ayah dapat berupa ketidakhadiran secara fisik, psikologis dan emosional dalam kehidupan anak. Menurut Smith (2011) seorang dikatakan mendapat suatu kondisi fatherless ketika tidak memiliki hubungan dekat dengan ayahnya, serta kehilangan peranperan penting ayah yang disebabkan oleh perceraian atau permasalahan pada pernikahan orang tua. Dapampak ketidak hadirnya peran ayah berupa fisik maupun psikologis dalam kehidupan seorang anakadalah rendahnya harga diri (self-esteem) ketika remaja beranjak dewasa, adanya perasaan marah (anger), anak akan merasakan kesepian (loneliness), rasa malu (shame) karena berbeda dengan anak lainnya (Sundari, A.R., \& Herdajani, 2013).

Berdasarkan urai di atas, maka dibutuhkan bantuan profesional berupa bimbingan konseling kreatif (Karneli, Y., Neviyarni, N., Firman, F., \& Yulidar, Y., 2020) untuk meningkatkan penyesuaiai diri siswa kemudia sosialisasi terkait pentingnya peran ayah. Adapun penelitian terdahu yang relevan denan penelitian ini adalah Hasil penelitian relevan sebelumya yang sesuai dengan penelitian ini adalah penelitian yang dilakukan oleh Sundari 
dan Herdajani pada tahun 2013 yang berjudul Dampak Fatherles terhadap Perkembangan Psikologis Anak di Fakultas Psikologi Universitas Persada Indonesia YAI. Penelitian ini bertujuan untuk dapat mengeksplorasi sampai sejauh mana dampak fatherless pada perkembangan pikologis anak. Untuk kemudian dapat dicari tindakan apa yang perlu diperbuat atas kondisi fatherless yang telah dialami oleh seseorang dan antisipasi yang dapat dilakukan terkait dengan pengasuhan dan peranan oleh ayah dalam pendidikan anak. Maka dari itu, berdasarkan dampak tersebut kehadiran seorang ayah sangatlah penting bagi remaja karena akan mempengaruhi kemampuan individu dalam menyesuaikan diri di lingkungan sosial dengan baik. Berdasarkan pemaparan latar belakang di atas, maka dalam penelitian ini akan mendekripsikan hubungan Fatherless Terhadap Penyesuaian Sosial Remaja di SMA Negeri 10 Jakarta Pusat Implementasi dalam Layanan Bimbingan Konseling.

\section{METODE}

Penelitian ini termasuk penelitian deskriptif kuantitatif dengan menggunakan pendekatan korelasional yang bertujuan untuk mengetahui seberapa besar hubungan antara variabel penelitian. Penelitian ini terdapat dua variabel yaitu variabel $\mathrm{X}$ atau variabel bebas (variabel yang mempengaruhi) yaitu fatherless dan variabel $\mathrm{Y}$ atau variabel terikat (variabel yang dipengaruhi) yaitu penyesuaian sosial. Penelitian dilakukan di SMA Negeri 10 Jakarta Pusat., Penelitian ini dilakukan di Sekolah Menengah Atas Negeri (SMAN) 10 Jakarta Pusat. Alasan peneiliti memilih SMA Negeri 10 Jakarta Pusat ini sebagai tempat penelitian karena belum ada yang melakukan penelitia tentang penyesuaian social dan fatherless di SMA tersebut.

Populasi yang digunakan dalam penelitian ini adalah seorang siswa remaja kelas XI SMA Negeri 10 Jakarta yang berjumlah 175 siswa, yang terdiri dari lima kelas, kelas XI MIPA 1, XI MIPA 2, XI IPS 1, XI IPS 2, dan XI IPS 3 yang masing-masing kelas berjumlah \pm 35 remaja. pengambilan jumlah sampel mengacu berdasarkan pada tabel Krejcie, yaitu dengan jumlah 175 dengan menggunakan kesalahan 5\% dan tingkat kepercayaan 95\% maka populasi berada di antara 170-180 dan sampel yang didapat adalah 123 siswa. Jadi, dalam penelitian ini diambil sampel sebanyak 123 siswa kelas XI SMA Negeri 10 Jakarta Pusat.

Instrumen yang digunakan untuk mengukur penyesuaian sosialsiswa menggunakan skala Likert yang akan disusun oleh peneliti berdasarkan aspek utama dari penyesuaian social yang telah dikemukakan oleh Harlock (1997) dan fatherless yang dikemukakan oleh Smith (2011). Adapun langkah-langkah untuk membuat instrumen ini adalah sebagai berikut: (1) Membaca berbagai literatur terkait denganpenyesuain social dan fatherless ; (2) .Berdasarkan kajian teori yang ada, maka akan disusun kisi-kisi instrumen berdasarkan teori penyesuaian social dan fatherless. Penyusunan kisi-kisi instrumen akan dimulai dari menjabarkan variabel sampai dengan butir-butir pernyataan dirumuskan unutuk mengungkapkan gambaran yang terkait dengan penyesuaian social dan fatherless siswa. penyesuaian social yang telah dikemukakan oleh Harlock (1997)terdiri dari indikator: (1) Penampilan nyata melalui sikap dan tingkah laku nyata; (2) Penyesuaian diri terhadap berbagai kelompok; (3) Sikap social; (4) Kepuasan pribadi dan fatherless yang dikemukakan oleh Smith (2011) yang terdiri dari indikator; (1) Memenuhi kebutuhan finansial anak untuk membeli segala kebutuhan anak; (2) Teman bagi anak termasuk teman bermain; (3)Memberi kasih sayang dan merawat anak; (4) Mendidik dan memberi contoh teladan yang baik; (5) Memantau atau mengawasi dan menegakkan aturan disiplin; (6) Pelindung dari resiko atau bahaya; (7) Memberi nasihat ketika ada masalah; (8) Mendukung potensi untuk keberhasilan anak. Selanjutnya peneliti melakukan uji validitas isi dan langkah berikutnya melakukan proses judgment untuk menetapkan kelayakan instrumen oleh para ahli untuk diuji coba. Langkah terakhir adalah melakukan uji validitas butir beserta uji reabilitas intrumen yang diperoleh fatherless dengan tingkat reabilitas 0,913 pada kategori sangat tinggi dan penyesuaian diri dengan tingkat 
Dwi Dasalinda ${ }^{1}$, Yeni Karneli ${ }^{2}$

COUNSENESIA Indonesian Journal of Guidance and Counseling

2 (2) (2021): 98-105

reabilitas 0,875 pada kategori sangat tinggi. Untuk menguji hipotesis penelitian yaitu terdapat hubungan fatherless dengan penyesuian social siswa, data yang sudah diperoleh dianalisis secara kuantitatif dengan menggunakan teknik uji koefisien regresi sederhana dengan bantuan SPSS 20.00 .

\section{HASIL DAN PEMBAHASAN}

Data hasil penelitian ini dihitung berdasarkan analisis data statistik, yang dapat diuraikan sebagai berikut:

\section{Penyesuaian sosial} berikut:

Hasil dari perhitungan kategorisasi variabel penyesuaian sosial diperoleh data sebagai

Tabel 1 Kategorisasi Penyesuaian Sosial

\begin{tabular}{lccc}
\hline \multicolumn{1}{c}{ Kategori } & Kriteria & Frekuensi & Persen (\%) \\
\hline Sangat Tinggi & $\geq 149$ & 31 & 25,2 \\
Tinggi & $113-148$ & 89 & 72,4 \\
Sedang & $77-112$ & 3 & 2,4 \\
Rendah & $41-76$ & - & - \\
Sangat Rendah & $\leq 40$ & - & - \\
Jumlah & & 123 & 100 \\
\hline
\end{tabular}

Dari tabel 1 di atas, dapat diketahui bahwa penyesuaian sosial pada siswa SMA Negeri 10 Jakarta Pusat berada pada kriteria Sangat Tinggi sebanyak 31 responden, pada kriteria Tinggi sebanyak 89 responden, pada kriteria Sedang sebanyak 3 responden, pada kriteria Rendah dan Sangat Rendah sebnayak 0 responden.

\section{Fatherless}

Hasil dari perhitungan kategorisasi variabel fatherless diperoleh data sebagai berikut:

Tabel 2 Kategorisasi Fatherless

\begin{tabular}{cccc}
\hline Kategori & Kriteria & Ftrekuensi & Persen (\%) \\
\hline Sangat Tinggi & $\geq 162$ & 63 & 51,2 \\
Tinggi & $128-161$ & 47 & 38,2 \\
Sedang & $89-127$ & 13 & 10,6 \\
Rendah & $50-88$ & - & - \\
Sangat Rendah & $\leq 49$ & - & - \\
Jumlah & & $\mathbf{1 2 3}$ & $\mathbf{1 0 0 , 0 0}$ \\
\hline
\end{tabular}

Dari tabel 2 di atas, dapat diketahui bahwa fatherless untuk mengatahui tingkat peran ayah pada remaja kelas XI SMA Negeri 10 Jakarta Pusat berada pada kriteria Sangat Tinggi sebanyak 63 responden, pada kriteria Tinggi sebanyak 47 responden, pada kriteria Sedang sebanyak 13 responden, pada kriteria Rendah dan Sangat Rendah sebanyak 0 responden.

Pengujian hipotesis dihitung menggunakan uji regresi sederhana, digunakan untuk mengetahui apakah variabel fatherless (X) berpengaruh secara signifikan terhadap variabel penyesuaian sosial (Y) dan data diolah menggunakan SPSS 24. sebagai berikut:

Tabel 3 Hasil Uji Hipotesis

\begin{tabular}{ccc}
\hline Variabel & Thitung $_{\text {Sig }}$ \\
\hline $\mathrm{X}_{1-\mathrm{Y}}$ & 6,700 & 0,000 \\
\hline
\end{tabular}


Tabel 3 menjelaskan diketahui nilai Sig. Sebesar 0,000<0,05, artinya jika Sig. < 0,05 maka $\mathrm{H}_{0}$ ditolak. Sehingga dapat disimpulkan bahwa variabel fatherless berpengaruh terhadap variabel penyesuaian sosial. Berdasarkan nilai t: diketahui nilai thitung sebesar 6,700 $>t_{\text {tabel }} 1,657$, sehingga dapat disimpulkan bahwa variabel fatherless berpengaruh terhadap variabel penyesuaian sosial. Maka hasil yang didapatkan dari hipotesis, yaitu: $\mathrm{H}_{\mathrm{a}}$ bermakna Ada Pengaruh Fatrherless (X) Terhadap Penyesuaian Sosial (Y) di SMA Negeri 10 Jakarta Pusat.

Kesimpulan dari hasil hipotesis terdapat pengaruh fatherless terhadap penyesuaian sosial remaja, jenis pengaruh pada penelitian ini yaitu pengaruh positif. Jika koefosien maka pengaruh variabel searah artinya jika variabel $\mathrm{X}$ tinggi maka variabel $\mathrm{Y}$ akan tinggi pula. Dikatakan positif karena hasil perhitungan data fatherless pada skala keterlibatan peran ayah berada pada kategori tinggi dan penyesuaian sosial berada pada kategori tinggi, yang artinya semakin tinggi fatherless maka semakin tinggi penyesuaian sosial yang akan dialami oleh remaja

Berdasarkan hasil pengujian hipotesis menggunakan uji koefisien regresi sederhana dapat diketahui nilai koefisien sebesar Sig. $0,000<0,05$, yang berarti $\mathrm{H}_{0}$ ditolak dan $\mathrm{H}_{\mathrm{a}}$ diterima. Artinya hal tersebut terdapat pengaruh fatherless terhadap penyesuaian sosial remaja kelas XI di SMA Negeri 10 Jakarta Pusat. Hubungan kedua variabel positif, karena tingginya variabel $\mathrm{X}$ searah dengan tingginya variabel $\mathrm{Y}$. Pada penelitian ini diketahui variabel fatherless ada pada kategori tinggi sedangkan penyesuaian sosial remaja di SMA Negeri 10 Jakarta Pusat termasuk dalam kategori tinggi.

Sumbangsih pengaruh fatherless terhadap penyesuaian sosial sebesar $27,1 \%$ yang artinya $72,5 \%$ dipengaruhi oleh faktor lainnya yang tidak diteliti dalam penelitian ini. Individu yang merasakan pengaruh fatherless terheadap penyesuaian sosial pastilah memiliki pola pikir yang berbeda. Hal ini terjadi karena pengaruh fatherless terhadap penyesuaian sosial sangatlah memiliki peran penting terhadap penyesuaian sosial oleh individu tersebut. Akan tetapi, pengaruh fatherless terhadap penyesuaian sosial pada aspek ini dapat dihindarkan, karena kemampuan remaja dalam menyesuaikan diri dengan lingkungan sosialnya tersebut dapat berjalan dengan baik.

Kemampuan remaja dalam menyesuaiakan diri dengan lingkungan sosial disebut penyesuaian sosial. Penyesuaian sosial remaja dapat dipengaruhi oleh berbagai faktor diantaranya yaitu kehadiran peran ayah dan ibu. Jika peran ayah tidak ada akan berdampak pada perkembangan baik fisik dan psikis remaja. Sebagaimana dinyatakan oleh Smith (Smith, 2011) bahwa seseorang dikatakan fatherless ketika individu tidak memiliki ayah atau tidak memiliki hubungan dengan ayahnya, disebabkan oleh perceraian atau permasalahan pada pernikahan orang tua.

Ketiadaan peran ayah akan berdampak pada rendahnya harga diri, adanya perasaan marah, malu karena berbeda dengan anak-anak yang lain. Oleh karena itu, peran orang tua sangat penting khususnya ayah dalam perkembangan remaja di lingkungan keluarga, sekolah, dan masyarakat. Hal ini seperti yang dikatakan oleh Hart dalam (Abdullah, 2010) tentang peran ayah dalam pengasuhan anak yang harus dilakukan diantara yaitu: memenuhi kebutuhan finansial anak untuk segala kebutuhan anak, teman bagi anak termasuk teman bermain, memberi kasih sayang dan merawat anak, mendidik dan memberi contoh teladan yang baik, memantau atau mengawasi dan menegakkan aturan disiplin, pelindung dari resiko atau bahaya, memberi nasihat ketika ada masalah, dan mendukung potensi untuk keberhasilan anak. Apabila keterlibatan ayah tinggi dalam arti ayah sudah berperan baik maka penyesuaian diri terhadap lingkungan sosial anak akan tinggi.

Penelitian yang terkait yaitu penelitian yang dilakukan oleh Siti Rahayu (Rahayu, 2020) yang berjudul "Pengaruh Fatherless dan Status Identitas Terhadap Kemampuan Penyesuaian Sosial pada Siswa SMA Negeri di Kota Bandung" yang menyimpulkan bahwa 
ketiadaan peran ayah pada remaha dan pencarian status identitas berpengaruh pada bagaimana siswa SMA Negeri di Kota Bandung dalam menyesuaikan diri pada lingkungan sosialnya.

Penelitian Siti Maryam Munjiat (Munjiat, 2017) yang menyimpulkan bahwa ketiadaan pera ayah baik secara fisik maupun psikis sangat berdampak dan berperan penting pada perkembangan anak. Tanpa peran ayah anak akan minder serta sulit sdaptasi dengan dunia luar. Selain itu, kematangan psikologis anak tumbuh melambat dan cenderung kekanakkanakan. Bahkan, anak cenderung lari dari masalah dan emosional saat menghadapi masalah. Dan anak kurang bisa mengambil keputusan atau ragu-ragu dalam banyak situasi yang membutuhkan keputusan cepat atau tegas.

Penelitian Krissakti Mohamad (Putra, 2018) menyatakan bahwa tugas perkembanan remaja tidak hanya di dalam rumah, namun juga diluar rumah berkaitan dengan lingkungan sosialnya, maka dari itu remaja harus mampu melewati tugas perkembangannya. Pada faktanya masih banyak remaja yang terhambat melewatinya. Kemampuan remaja dalam menyesuaikan diri dengan lingungan sosial disebut penyesuaian sosial. Remaja yang memilii kemapuan rendah dalam penyesuaian sosial akan bedampak buruk pada dirinya. Tidak hanya ibu, ayah juga memiliki peluang sama dengan ibu dalam mengasuh anak secara intens sehingga mampu meningkatkan penyesuaian sosial anak. Berdasarkan penjelasan di atas maka dapat disimpulkan terdapat pengaruh fatherless terhadap penyesuaian sosial remaja di SMA Negeri 10 Jakarta Pusat. Pengaruhnya positif karena kenaikan variabel $\mathrm{X}$ diikuti dengan kenaikan variabel Y, kontribusi fatherless terhadap penyesuaian sosial adalah $27,1 \%$ dan 7 $2,9 \%$ disebabkan oleh faktor eksternal lainnya yang bersifat positif

\section{PENUTUP}

Terdapat pengaruh yang positif antara fatherless dengan penyesuaian sosial remaja di SMA Negeri 10 Jakarta Pusat, dengan nilai Sig. Sebesar 0,000<0,05 dan nilai thitung 6,700> $\mathrm{t}_{\text {tabel }}$ 1,657. Variabel fatherless memberikan sumbangsih pengaruh sebesar $27,1 \%$ terhadap penyesuaian sosial remaja dan 72,9\% dipengaruhi oleh faktor lain. Pengaruh pada penelitian ini yaitu pengaruh positif. Jika koefisien maka pengaruh variabel searah artinya jika variabel $\mathrm{X}$ tinggi maka variabel $\mathrm{Y}$ akan tinggi pula. Dikatakan positif karena hasil perhitungan data fatherless pada skala keterlibatan peran ayah berada pada kategori tinggi dan penyesuaian sosial berada pada kategori tinggi, yang artinya semakin tinggi fatherless maka semakin tinggi penyesuaian sosial yang akan dialami oleh remaja.

Implimentasi hasil penelitian dalam pelaksanaan bimbingan konseling di sekolah, dapat dimanfaatkan sebagai layanan informasi terkait pentingnya penyesuain sosial bagi remaja. Kemudian dapat dimanfaatkan sebagai landasan untuk melaksanakan layanan konsultasi terkait dengan pemtingnya peran ayah dalam mendidik, memberikan perhatian, menyesuaikan pola pengasuhan berdasarkan karakter anak. Peranan tersebut sangat penting dan berdampak pada penyesuaian sosial remaja baik dilingkungan masyarakat maupun di sekolah.

\section{DAFTAR PUSTAKA}

Abdullah, S. M. (2010). Studi eksplorasi tentang peran ayah dalam pengasuhan anak usia dini. Jurnal Spirits, 1(1), 3-4.

Afiatin, T. 2001. Persepsi Terhadap Diri dan Lingkungan Pada Remaja Penyalahguna Napza. Psikologika, No. 12, VI, 11-28.

Ali, M. (2004). Psikologi remaja perkembangan peserta didik. B. Aksara

Andriyani, J. (2016). Korelasi peran keluarga terhadap penyesuaian diri remaja. Jurnal AlBayan: Media Kajian dan Pengembangan Ilmu Dakwah, 22(2).

Hurlock, E. (1994). Psikologi Perkembangan, Suatu Pendekatan Sepanjang Rentang. Kehidupan. Jakarta: Erlangga. 
Dwi Dasalinda ${ }^{1}$, Yeni Karneli ${ }^{2}$

COUNSENESIA Indonesian Journal of Guidance and Counseling 2 (2) (2021): 98-105

Hurlock,E. (2000). Psikologi Perkembangan,Suatu Pendekatan Sepanjang Rentang. Kehidupan. Jakarta: Erlangga.

Inayati, A. (1995). Peran Ganda Seorang Ayah. Kartini no. 548, 5-14 Juni. Jakarta.

Kristianawati, E., \& Djalali, M. A. A. (2014). Hubungan antara kematangan emosi dan percaya diri dengan penyesuaian sosial. Persona: Jurnal Psikologi Indonesia, 3(03).

Lamb, M. E. 1992. The Role of The Father in Child Development. New York: John Wiley and Sons, Inc.

Lestari, D. S. (2016). Penyesuaian sosial pada mahasiswa tuli. INKLUSI Journal of Disability Studies, 3(1), 101-134.

Lestari, S, 2012. Psikologi Keluarga Penanaman Nilai dan Penaganan Konflik Dalam Keluarga. Jakarta: PT Kencana Prenada Media Group, hlm 22

Maharani, O. P., \& Andayani, B. (2003). Hubungan antara dukungan sosial ayah dengan penyesuaian sosial pada remaja laki-laki. Jurnal psikologi, 30(1), 23-35

Munjiat, S. M. (2017). Pengaruh Fatherless terhadap Karakter Anak dalam Perspektik Islam. Jurnal Pendidikan Islam, Vol.2, 108-116.

Nurhusni, P. A. (2017). Profil penyesuaian sosial remaja yang mengalami kecanduan mengakses facebook. Indonesian Journal of Educational Counseling, 1(2), 129-144.

Putra, K. M. D. (2018). Pengaruh Keterlibatan Ayah dalam Pengasuhan terhadap Penyesuaian Sosial Remaja. SKRIPSI. Universitas Muhammadiyah Malang

Papalia, D E., Olds, S. W., \& Feldman, Ruth D. (2001). Human development (8th ed.). Boston: McGraw-Hill.

Kartono, M. (2005). Perbandingan perilaku agresif antara remaja yang berasal dari keluarga bercerai dengan keluarga utuh. Jurnal Psikologi Vol, 3(1), 1.

Kumalasari, F., \& Ahyani, L. N. (2012). Hubungan antara dukungan sosial dengan penyesuaian diri remaja di panti asuhan. Jurnal Psikologi: PITUTUR, 1(1), 19-28.

Sari, M. Y. 2005. Kecerdasan Emosional dan Kecenderungan Psikopat Pada Remaja Delinkuen Di Lembaga Pemasyarakatan. Anima Vol 20 No 2 halaman 139-148.

Rahayu, S. (2019). Pengaruh fatherless dan status identitas terhadap kemampuan penyesuaian sosial pada siswa SMA Negeri Di Kota Bandung (Doctoral dissertation, Universitas Pendidikan Indonesia).

Sundari, A.R., \& Herdajani, F. (2013). Dampak Fatherless Terhadap Perkembangan Psikologis Anak. Jurnal Psikologi, vol.1, 256-271.

Susilowati, E. (2013). Kematangan emosi dengan penyesuaian sosial pada siswa akselerasi tingkat SMP. Jurnal Online Psikologi, 1(1), 101-113.

Suharti, N. (2016). Bimbingan kelompok untuk meningkatkan penyesuaian sosial siswa kelas IX-E SMP Negeri 1 Wonoasri Kabupaten Madiun. Counsellia: Jurnal Bimbingan dan Konseling, 4(2).

Smith, D. (2011). Father's Day For The Fatherless. Dipublikasikan 18 Juni 2011 oleh Darcy Smith. in Ask Dr. Darcy. (online), (http://www.psychologytoday.com/blog/askdrdarcy, diakses pada 3 November 2014).

Strom, R. D. 2002. Evaluating The Success of Caucasian Fathers in Guiding Adolescents. www.findarticles.com.

Wardani, R., \& Apollo. (2010). Hubungan Antara Kompetensi Sosial Dengan Penyesuaian Sosial Pada Remaja. Jurnal Widya Warta, 34 (1), 93-95.

Wardani, R. (2010). Hubungan antara kompetensi sosial dengan penyesuaian sosial pada remaja. Widya Warta: Jurnal Ilmiah Universitas Katolik Widya Mandala Madiun, 34(01), 92-103.

Karneli, Y., Neviyarni, N., Firman, F., \& Yulidar, Y. (2020). Pengembangan modul konseling kreatif dalam bingkai modifikasi kognitif perilaku untuk menurunkan perilaku agresif siswa. Jurnal Bimbingan Dan Konseling Ar-Rahman, 6(1), 43-49. 